\title{
Things and places from the city. Consumption practices, settlement and belonging of second generation migrants in Lisbon
}

\author{
Marta Vilar Rosales \\ PhD in Social and Cultural Anthropology (Universidade Nova de Lisboa) \\ Research fellow at Institute of Social Sciences, University of Lisbon \\ Visiting Professor at Universidade Nova de Lisboa \\ Lisboa, Portugal \\ marta.rosales@ics.ul.pt
}

\begin{abstract}
While much scholarly work has been produced on the complex topic of contemporary migration, there is still relatively little literature on its intersections with material culture and consumption practices. Yet the impact of migration on material experiences goes beyond attachment to objects from home; it can change peoples' perceptions of themselves, restructure their patterns of social interaction and, I believe, alter the balance of relationships maintained not just with those left behind but also with those who migrated to other localities as well as those who share and inhabit the same places. Drawing on the results of an ethnographic study carried out in Lisbon with teenage boys and girls of African descent, this paper aims to explore the interface between migration, materiality and place and, more significantly still, how personal, cultural and geographical trajectories, and positioning and belonging policies are marked and partially constituted through the relationship with mass produced goods which are acquired and used in very specific urban contexts. The article introduction will draw particular attention to two aspects. The first stems from the fact that everyday things such as clothes, mobile phones, sneakers, food and music would seem to be appropriated according to a specific logic in order to materialize the teenagers' collective identities and positioning strategies in specific key places such as the neighbourhood, school or city centre where they sometimes go clubbing and shopping. The second concerns the existence of an intense on-going transnational circulation of objects, which informs the existence of a complex social network based in multiple locations. Besides contributing to the maintenance and strengthening of family relationships, the continuous circulation of goods stimulates the production of a hierarchical representation of the world - a constellation of different places linked by complex transnational networks - and therefore of the best migration destinations, based on what is sent and received.
\end{abstract}

Keywords: migration; belonging; place; youth; material culture.

\section{Introduction}

The debate on contemporary migrations has become particularly intense in the last decade. Despite the range and complexity which characterize the on-going discussions in the Social Sciences, the need to think about the multiple consequences of movement in terms of its impact on cultural diversity, social reproduction and communal life has gained visibility in recent years. At present, the idea of the journey as a 
single movement from a fixed origin to a pre-defined destination is being questioned more and more by the concept of migration 'as a continuous process' of movements between various locations, which contributes not only to its visibility but also to its instability and fluidity. In addition, the 'transnational turn' (Glick Schiller 2008; Vertovec 2009), has also meant a significant change in studies of migration, by way of shifting the analysis from groups in specific locations to groups and their activities as they engage in cross-border, multi-local processes and practices.

While much scholarly work exists on migration, there is little literature on its intersections with material culture and consumption practices (Basu and Coleman, 2008). But all migrations are embedded in materiality since they necessarily involve sending and receiving things, as well as processes of expropriation and appropriation, desire and expectation regarding objects. As recent studies demonstrate (Burrell 2008; Fryman 2009; Rosales 2009) ethnographic insights into migrants' relationships and networks achieved through objects constitute productive conceptual lenses in migration studies. The impact of migration on material experiences goes beyond attachment to objects from home; it can change peoples' perceptions of themselves, restructure their patterns of social interaction, alter the balance of the relationships maintained with those left behind and those who migrated to other localities as well as, I consider, being part of the production of relationships with specific key places. Furthermore, material culture is an invaluable tool, not only for objectifying the strategies which migrants develop to relate to new (geographic, social, cultural) contexts, but also for expressing how they are evaluated in terms of appropriation and belonging.

Drawing on the results of an ethnographic study conducted in Lisbon with teenage boys and girls of African descent, this paper aims to explore the interface between migration, materiality and the production of place and, more significantly still, how personal, cultural and spatial trajectories, and positioning and belonging policies are marked and partially constituted via "things in motion".

The paper will focus on two main features. The first is associated with the fact that the teenagers seem to appropriate objects of everyday use, such as clothes, mobile phones, sneakers, food and music, according to a specific group logic in order to materialize their collective identity. The valorisation of certain styles as opposed to others, the production of classificatory typologies based on the uses of things to translate and confirm social positions proves not just the expressive potential of mass produced objects, but also and more meaningfully, their ability to domesticate them and review their social meanings. The second feature relates to the multiple origins of the objects consumed. Though most were acquired in Lisbon near their homes, some are meaningful objects which have travelled from other locations such as Angola or Cape Verde, Brazil, Holland or the UK. And this permanent circulation of things is contributing to maintaining and strengthening family relationships, as well as to producing a hierarchical representation of the world based on these movements and on the kind of objects which come and go from and to these different locations. This analytical option proved to be productive in relation to a third relevant aspect. It contributed to the emergence of a discourse which points to the existence of different positions regarding key places such as neighbourhoods, schools, and city centre sites where these groups of young people, like many others, go clubbing, drinking and socializing.

\section{Migration, material culture, place}

The Social Sciences and, in particular, Anthropology have always devoted attention to material culture as an invaluable field of practice, central to the understanding of non-industrialized contexts. However, in industrialized capitalist societies, objects 'as visible parts of culture' (Douglas and Isherwood 1979) and their uses have only regained centrality by means of a set of relatively recent theoretical productions (Baudrillard 1968; Douglas and Isherwood 1979; Bourdieu 1979; Appadurai 1986; Miller 1987) which, without undermining the discussion on the impact of capitalist production, stressed the urgency of rethinking contemporary materiality and its relationships with subjects. The importance of contemporary objects and consumption practices in generating culture is re-established and their ability to undertake social and cultural work through processes of differentiation, objectification and integration gains visibility, based on a cluster of theoretical premises that acknowledge that things can be perceived as objectification devices, which are actively involved in processes of social evaluation, positioning and mobility (Bourdieu 1979; Miller 1987). Consumption can, therefore, be defined as a set of practices involving acquiring, using and reusing things whose meanings are adjusted according to the subjects they meet and the contexts they enter (Douglas and Isherwood 1979; Kopytoff 1986; Miller 1987).

In keeping with the first two premises, the definition and status of contemporary materiality undergoes a major revision. Objects cease to be understood as "neutral" entities in their relationships with the subjects and therefore participate in and 
are responsible for the co-production of the places they enter and inhabit (Appadurai 1986; Miller 1987; Latour 1997). In addition, they compose a familiar frame, a subtle setting for social practice, and since much of social behaviour is cued by expectations and determined by frames, they ensure appropriate behaviour without leaving themselves open to challenge (Miller 2010). In conclusion, it is worth drawing attention to the fact that materiality constitutes a "key tool", i.e. a socialization device, for defining groups' particular identities and their ways of seeing the world, which means that interacting with things can be understood as a learning process of collective norms (Bourdieu 1979).

Contemporary migrations, like material culture and consumption, have been vigorously debated in recent years by all the social disciplines. From the plurality of contributions generated, two main features stand out: their sharp visibility and intrinsic diversity. The work of authors such as Hannerz (1989), Appadurai (1990), Glick Schiller et al (1995), Portes (1999) or Vertovec (2007), amongst others, are central references, since they all point towards the need to think out the multiple consequences of contemporary movements in terms of their impact on cultural diversity, social reproduction and communal life. All this visibility does not however depict a world of 'fluidity and openness'. On the contrary, most migrations are based on inequality and discrimination, and are controlled and limited by States (Castles 2010). Awareness of complexity, diversity and context in contemporary migration does not stand up to postmodern fragmentation. Contemporary migrations do present great diversity, but this diversity unfolds within increasingly universal relationships of power, frequently translating the existence of global "structures of common difference" (Wilk 1995). Migration should therefore be addressed by focusing on the specificities, complexities, contradictions and even unintended consequences, while exposing the regularities and variations that these movements, and the relationships which support them, might entail (Portes and Dewind 2004).

As mentioned before, transnationalism has introduced significant changes in the migration debate, by way of shifting the analysis from groups in specific locations to groups and their activities as they engage in cross-border, multi-local processes and practices without undermining the centrality of community, kinship, residence and other more or less stable forms of affiliation and belonging (Fortier 2000; Gardner 2002). Migration experiences are grounded on detail: who leaves and who stays, when, how and in what circumstances; what historic, economic, political and cultural conditions mark the contexts and trajectories of migration and its impact over time on personal biographies; how relationships and networks of belonging are managed and portrayed.

While much scholarly work has been produced on migration, there is a scarcity of literature on its intersections with material culture and place. Yet, all migrations are embedded in materiality since they necessarily involve carrying, sending and receiving things, as well as expropriation and appropriation, desires and expectations regarding objects. As recent studies demonstrate (Burrell 2008; Fryman 2009; Rosales 2009) ethnographic insights into migrants' relationships and networks garnered through objects constitute productive conceptual lenses in migration studies. If movement affects materiality because it implies the transfer of objects and practices from one physical location to another, thereby changing its uses as well as its users, and if different movements result in distinct materialities, since things act diversely depending on the routes taken and on sites of departure and destination (Howes 1996), then what needs to be further explored is how the "itineraries of people and things are mutually constitutive" (Basu and Coleman 2008) and how they contribute to the production of particular places.

\section{Hang around in and outside the neighbourhood: routines, consumptions and sociability practices}

The ethnography on which this paper is based was carried out in one of the largest residential areas on the outskirts of Lisbon. At present, mainly working class and lower middle class families populate this relatively new urban area which has grown very rapidly due to the powerful on-going attraction that the capital city exerted on people from other Portuguese regions and, after decolonization, on people coming from the former African colonies.

The parents of the boys and girls who took part in this research participated in the intense migration movement which was responsible for the arrival of a million and a half people in Portugal during the late 70s. They all came from the former Portuguese African colonies. Most of these boys and girls were born in this same neighbourhood and had never lived, not even for a short period, in their parents and/or grandparents' country of origin. All these migrations, while presenting specificities resulting from the different political contexts out of which they arose, were strongly influenced by the historical ties 
that bound Portugal and its former colonies together, a key particularity which needs to be taken into consideration when addressing the positioning and integration strategies of these groups in contemporary Portugal.

Second and third generations of former migrants from Portuguese speaking African countries comprise a vast number of individuals. Their significance stands out, especially when compared with the number of descendants of other origins which, in certain cases, make up larger migrant contingents, such as the Brazilian and the Ukrainian, but which are nevertheless outnumbered.

The research involved seventeen subjects, six girls and eleven boys aged between twelve and twenty-three. The first approaches took place in neighbourhood schools and youth associations. After the first mediated contacts it became possible to include other subjects in the research via informal encounters in different places of leisure. The fact that first contacts made simultaneously with diverse subjects and which occurred in several spatial contexts proved to be productive, led to observations in both formal and informal environments, such as schools, homes, neighbourhood streets, cultural and sports associations, shopping centres and places for nightlife socializing, such as bars and clubs.

Recent debates on the theme of the "second generations" have started to examine the theoretical and methodological approaches which focus on structural variables such as "degree of formal education" (cultural capital), "professional skills" and "positions occupied in the labour market" to depict the lives of these particular groups of migrants, especially in the sphere of integration policies and strategies in new spatial and cultural contexts. Without questioning their significance for depicting second generation trajectories, it is perhaps time also to inquire about the significance of other variables and dimensions when addressing these subjects. No matter how the former are evaluated, culture, ethnicity, religion (Thompson and Crul 2007), material culture and consumption practices can also positively contribute towards describing and discussing the complexities of these projects, since they necessarily refer to other equally significant routines and practices, as well as to other less formal socialization spheres and places of belonging. This theoretical and methodological position is especially significant if more formal variables, such as those related to school achievements and/or integration into the labour market, are positively evaluated. An approach grounded on everyday consumption (food, clothing, sneakers, mobile phones, mp3) and other expressive associated practices, such as music and dance, emerge as a productive path to addressing particular groups such as these which, like most young Portuguese people, are experiencing a particularly intense (life) stage in terms of identity evaluation and management, social and cultural belonging and positioning negotiation in various strategic spheres and places, such as (transnational) family, work, school, neighbourhood and the city. With and through familiar objects and their uses, subjects talk not only about themselves and their worlds (Frykman 2009; Miller 1995), but also work on key dimensions with regard to their identity and places of reference and belonging, and therefore express the existence of permanent negotiation processes with the social reality of which they are part, while allowing for access to analytic dimensions that are not often present in the subjects' discourses about the logic which structure their daily lives.

Peter and $\mathrm{Gu}$ like to visit a street-wear shop located in Bairro Alto, one of the 'in places' in which to shop and hang around in the centre of Lisbon. The two boys come here often, to check out the latest styles, chat with the staff (from whom they eventually get discount prices), and meet some new people. These two 20 and 23-year-old cousins live together in an apartment in a social housing complex, in the neighbourhood. Though they also spend time there, they soon informed us that they were more interested in expanding their social network beyond the neighbourhood. When questioned about this matter, they argued it "all had to do with girls". In their words, "the girls from the neighbourhood are shabbily dressed, they just want to stay there and go to parties there, (and) they don't like to do the same things as we do". After this first reaction, they engaged in a discussion about who was first in their group of friends to develop "good taste" and stop dressing in a "shabby" manner. Then, they explained that the way the neighbourhood girls dressed wasn't "nice" and that they were too attached to more traditional ways of socializing and dating, such as weekend gatherings at friends' houses where people ate traditional food, listened and danced to Angolan music like kuduro, semba or kizomba. Not that Peter and Gu don't attend these parties. In their own words, they just don't do so "on a regular basis" since they are mostly interested in other more "cool" leisure contexts located outside the neighbourhood and frequented by other social groups. In fact, they were very skilled kuduro dancers, as we discovered during the research, which in their opinion could be a plus in attracting the attention of other non-migrant youngsters, especially girls, in the bars and discos of Bairro Alto and other fashionable places where Lisbon's middle class teenagers spend their weekend nights. This particular kind of music became very popular among Portuguese youngsters after the Buraka Som Sistema band, made up of Angolans and 
Portuguese who mixed the traditional kuduro with electronic music, became a huge success, not only in Portugal but also internationally.

Girls and boys in the group often get together at school. They spend most of their school breaks rehearsing new dance steps and choreographies, while one of their mobile phones pumps up the beat. This is not an activity performed exclusively by students of African descent. Their Portuguese colleagues join them regularly and try to keep up with all their rhythmic movements. At times like these, group borders and policies of belonging can seem almost non-existent, though in different situations, these same kids can be swiftly pushed back into their ethnic groups as in the case of 16-year-old Nadia. On one occasion when she was singing a famous Portuguese song she was interrupted by one of her colleagues who expressed incredulity at the fact that a "black girl knew how to sing that song so well".

Sixteen-year-old Élio goes to the same school as Peter and $\mathrm{Gu}$. Like them, he too was very anxious to go out at night to one of these famous clubs in the city centre, far away from his neighbourhood. While talking with another friend who had already been there, he mentioned that he was feeling very insecure because he wasn't sure how to behave in order to be admitted. He seemed afraid that the doorman wouldn't let him in because "I'm black", but his friend laughs and explains that acceptance in clubs has nothing to do with the colour of one's skin, but only with "one's style", and then starts describing exactly what kind of clothes (and labels) Élio should wear in order to feel confortable, not only in the club, but also in that particular part of the city where the club is located.

Most of the other boys also identify with the same clothing style, described by Élio's friend, and often set off by the latest mobile phone model, mp3, and even games for console players: " $M y$ favorite labels are DC, Element, Lot 29, Nike, Adidas. (...) They mean I have good taste. I also like Carhartt and LRG. (...) These labels make me feel like a guy from the Red Bull team, and that I'm at the top." In fact, when they are not actually in their own neighbourhood, most of the groups' leisure time is spent in shopping centres where they don't buy very often but just walk around with their friends, engaging in discussions about the items found in the shops, planning and imagining their next purchases, or just showing off to the other groups of young people which also hang out there. With the exception of $\mathrm{Gu}$ and Peter who usually spend a lot of time in Bairro Alto (one of Lisbon's night districts), the other girls and boys only seem to leave the neighbourhood to go to shopping centres. Although most of them were born in Lisbon, their knowledge of the city is restricted to other suburban residential quarters where their relatives live or to the shopping centres in surrounding areas: "after school I usually go home. That is, when I don't have a boyfriend. When I do, we go for a walk, sometimes to Colombo (largest shopping centre in Lisbon). Most of the time, we don't move very far from the neighbourhood".

\section{Social networks, objects in motion and production and future migrations}

$\mathrm{Gu}$ holds a part time job in one of the shopping centres that the group usually visits. He explains that this job is only temporary, while he tries to finish high school and apply for a music production course in a famous arts and media school in downtown Lisbon. One day, Peter and he were there walking around looking in shops for a list of specific items Peter's sister had asked him to buy and send over to Angola. Gu explains that requests like this from family members living in Angola are made all the time. Relatives ask for all sorts of things, from music CDs, clothes and fashion accessories to decoration objects for their homes. Buying the correct or most fashionable items is considered a highly complex task. According to Peter, few people in the neighbourhood know how to do so properly, since most do not know enough about what objects to buy, the latest most popular trends, or where to find them. In his words, they don't even feel confortable in Lisbon's fashion district, since they consider that it is not "their place". And in addition, they haven't met the salespeople from the trendier boutiques in Lisbon. In his opinion, that's an activity that takes time and effort and should therefore be highly prized: "the people from the neighbourhood think that I've got style. And I ask themdo you want it? Then you have to pay me! A few days ago, my sister asked me to buy her a watch that you can't find in Angola and I bought it at a discount because I know the people from the shop. And I kept the change!"

Transactions also take place in the opposite direction, from Angola to Portugal and also between other European countries where family and friends reside. What comes in from Angola is mainly music and food, as well as hairstyle products and Brazilian items, especially clothes, which are easier to find in markets in Angola than in Portugal: "sometimes we ask our family in Angola to send us clothes, not Angolan but Brazilian clothes, such as jeans and underwear. They're better and cooler than the Portuguese type. (...) As for Angolan clothes, the traditional clothes that our parents sometimes still wear, we are not interested in wearing them regularly. (...) Sometimes we wear them for Carnival, just 
for fun or on special family occasions just to please our parents and grandparents. (...) Our parents also ask for some specific food items; although they are also to be found here, they say that those from home taste better".

Although there are objects and products directly related to their origin in their homes, they are less appreciated than goods from other places. According to all the subjects, African food, clothes, objects and music are present in family gatherings most of the time but are not part of the daily routine of households: "my mother only prepares African food on special occasions, like birthdays and christenings"; "(...) what? Of course I don't wear those large African dresses. My style is very preppy! Like most girls of my age!"

Goods coming from England, Holland and Germany are usually most appreciated and treasured, since they are usually brands and models difficult to find in Portugal. On the other hand, items going from Portugal to other European countries are mainly food products which are difficult to find in Northern countries but easily acquired in Lisbon. In contrast with the objects and food sent from home, which are primarily intended for domestic consumption, things sent from other European countries are mainly to show off. Élio especially treasures the football boots his godfather sent him from Manchester, and wears them for all his football matches. He dreams of moving to live with his godfather and playing professional football in England. Like Élio, most of his friends also consider that clothes from other European countries are better than those to be found in Portugal: " $M y$ relatives from England send me clothes of English labels. I have cousins the same age as myself and we like to wear the same kind of things, though theirs are better because mine are bought in Portugal and theirs are from there. I sometimes go and visit just to buy cool stuff in labels such as McKenzie and Lonsdale that we can't find here in Portugal".

The idea of migrating to another country is quite common among the group. Though nobody expressed the intention of returning to their parents' country of origin, a move to another European or even North American "richer" country is positively considered. In fact, all subjects declare Portugal is their home country and, though they sometimes feel discriminated, they would only consider migrating if the kind of life they aspire to were impossible, and then preferably to destinations where they already have family. Peter, for instance, states that he can't identify with the Angolan life style which, according to him, is basically spending the day not doing much and going partying at night, something he is not used to and does not understand since he has lived all his life in Portugal. And he adds: "well, Portugal is one of the best places in the world to live; you just have to have money. If I had to migrate, I'd go to a very organized country, like, Canada or Australia".

\section{Conclusion}

Ethnographies are often difficult to finalize. The diversity and intensity of the information collected during research continually suggests new paths to follow and raises new issues and terrains to explore. Nevertheless, the data herein presented suggests certain main lines of inquiry worth highlighting.

The first is that of a methodological nature, and points towards the potential that research work focused on the everyday might hold for an analysis and discussion of youth identities in general, and of young migrants' daily realities in particular. With a view to giving visibility to the invisible routines of everyday life, these approaches permit one to observe the spaces and places where their social and cultural life takes place, through a lens that draws attention to the centrality of naturalized practices and discourses and their expressive competences. It also inspires integrated views on the subjects' realities, as well as a discussion of the regularities and singularities found to characterise them. This stance is fundamental for an understanding of the many relevant dimensions which resist the gaze of the researcher when addressed in a fragmented manner.

The second line of discussion, directly related to the first, calls for the need to contextualize and ground the reflections produced on social phenomena. The deconstruction of the dominant representation which depicts the practices of young migrants as homogeneous depends on this, since it allows one to create conditions conducive to the emergence of originality and the expressive characteristics of migrant identities while, at the same time, situating behaviour, clarifying positions and framing specific practices.

The third line of discussion draws attention to the centrality that leisure and sociability practices would seem to hold in the lives of young people and, consequently, in their consumption practices. Such practices, based on original, though highly normative, informal principles are a key dimension in the different places (home, school, neighbourhood, Bairro Alto) where they take place and in the structuring of the different consumption practices observed. According to the testimonies gathered, the consumption of music, food and clothing is almost always linked to conviviality. Clothes are bought for parties and evenings out with friends, music is played within the group in schoolyards and at home with friends, and family meetings are organized around specific meals. Being transversal to the majority of representations of young people's daily routines, the importance given to leisure and conviviality assumes, however, specific expressive dimensions through 
the objects and consumption practices associated with them. Clothes, mobile phones and sneakers are appropriated according to a specific logic in order to materialize specific identities both with the peer group and society. The analyses of certain styles as opposed to others, the construction of typologies of classification based on the intake and use of certain objects and/or services to translate social positioning, not only demonstrates the expressive potential of mass produced "things", but also the capabilities of the subjects to domesticate them and attach specific meanings to them.

Consumption provokes another, and perhaps more significant, comment. In his book on cross-cultural consumption, David Howes (1996) introduces the theme through a provocative question pointing to the need to (re)consider the procedures for the allocation of an ethnic identity to mass produced objects circulating in global markets. A reading of the text calls for the need to take into account how and to what extent ethnic identity is involved in the structuring of contemporary consumption practices, and especially in the modalities found to express it through apparently global things, goods and services. Since the risk of thinking that widespread access to these goods and services could result in the homogenization and loss of cultural specificity has been superseded, one can presume that the ability to assign specific local meanings to things designated as "global products" confers on contemporary material culture a special significance in understanding and discussing those specificities.

The research illustrates that second generation migrants, like most (young) people, develop original modalities to appropriate contemporary mass culture, by integrating them into their daily routine and use, and by combining them with other sets of objects, some of which are directly linked to their ancestral cultural backgrounds. It shows how relationships with older generations and relatives and friends living in other places materialize and often result from the continuous transnational movement of specific products, which circulate through a complex network of connections between Africa and Europe. Furthermore, these continuous movements also contribute to the emergence of a particular perspective on potential future migration destinations. Things which are most appreciated come from those same locations identified by these young boys and girls as potential places to live in the future. They therefore objectify and somehow appear to contribute to the stabilization of resources for the future, while intensifying and reinforcing their networks of belonging. Parallel to the production and definition of "us", the use of material culture was also observed as an instrument of confirmation, negotiation and redefinition of boundaries between "us and them" and "here and there", particularly through music, dance, food and foodways. And the concept of place continues to play a significant role in this whole process. Not only is it relevant but it contributes towards a hierarchical organization of the world, the grounding of specific experiences and the positioning of strategies. Moreover, they seem to be mutually constitutive, since they jointly work for the production of identifications, the outline of the other, and the rise and fall of cultural and spatial barriers. If anything, place presents more complex and unstable contours today, making it more challenging to address.

The last line of discussion worth mentioning here is directly derived from the concept of ethnicity in the context of contemporary migration research. It is central to the structuring of the consumption practices of the young migrants who make up this particular research, and seems to compete and intersect with other variables, also crucial in discussing the matter being analized. Variables such as economic, social and cultural capital, gender, age, transnational networks and even the social composition of key spatial settings such as the neighbourhood and school, seem to play a central part in the lives of these young people and in their expectations for the future. While they are often absent in terms of the dominant discourse, which tends to emphasize ethnicity and the "migrant condition", these other variables which emerged via observation of the subject's practices in general and of consumption practices in particular, proved to contribute positively to a broad understanding of these young people's subjective realm of existence. 


\section{References}

APPADURAI, A. (ed) (1986) The Social Life of Things, Cambridge, Cambridge University Press.

BASU, P. and S. COLEMAN (2008) "Introduction: Migrant Worlds, Material Cultures”, Mobilities, 3: 3, pp. 313-330.

BAUDRILLARD, J. (1968) Le Système des Objects, Paris, Gallimard.

BOURDIEU, P. (1979) La Distinction, Critique Sociale du Judgment Paris, Minuit.

BURREL, K. (2008) “Managing, Learning and Sending: The Material Lives and Journeys of Polish Women in Britain”, Journal of Material Culture, 13; 63, pp. 63-83.

CASTLES, P. (2010) Castles 2010 "Understanding Global Migration: A Social Transformation Perspective", Journal of Ethnic and Migration Studies, 36, 10, pp. 1565-86.

DOUGLAS, M. and Isherwood, B. (1979) The World of Goods, London, Routlege.

FORTIER, A. (2000) Migrant Belongings: Memory, Space and Identity, Oxford, Berg.

FRYKMAN, M. (2009) "Material aspects of Transnational Social Fields: An introduction", Two Homeleands, 29, pp 105-114.

GARDNER, K. (2002) History Narrative, Age and Migration: Life and the Life Course Amongst Bengali Elders in London, Berg, Oxford, 2002.

GLICK SCHILLER, N. et al (1995) "From Immigrant to Transmigrant: Theorizing Transnational Migration", Anthropological Quaterly, 68,1, pp. 48-63.

GLICK SCHILLER, N. (2008) "Beyond Methodological Ethnicity: Local and Transnational Pathways of Immigrant Incorporation", Willy Brant Series of Working Papers, 2/08, Malmo, Malmo University.

HANNERZ, U. (1999) Transnational Connections. Culture, People, Places, London, Routledge.
HOWES, D. (1996) Cross Cultural Consumption. Global Markets Local Realities, London, Routledge.

KOPYTOFF, I. (1986) "The Cultural Biography of Things: Commoditization as Process", in APPADURAI, A. (ed.), The Social Life of Things, Cambridge, Cambridge University Press, pp. 64-91.

LATOUR, B. (1997) Nous n’Avons Jamais Été Modernes. Essai d'Anthropologie Symétrique, Paris, la Découverte.

MILLER, D. (1987) Material Culture and Mass Consumption, Oxford, Blackwell.

MILLER, D. (1995) "Consumption and Commodities", Annual Review of Anthropology, 24, pp. 141-161.

PORTES, A. (1999) Migrações Internacionais, Oeiras, Celta. PORTES, A. and DeWIND (2004) "Conceptual and Methodological Developments in the Study of International Migration", International Migration Review, 38, 3.

ROSALES, M. (2009) "Objects, scents and tastes from a distant home: Goan life experiences in Africa", Two Homelands, 29, pp. 154-76.

THOMPSON, M. and M. CRUL (2007) “The second Generation in Europe and the United States: How is the Debate Relevant for Further Research on the European Second Generation?", Journal of Ethnic and Migration Studies, 33, 7, pp 1025-41.

VERTOVEC, S. (2007) "Introduction. New Directions in the Anthropology of Migration and Multiculturalism", Ethnic and Racial Studies, vol. 6, n 6, pp 961-978.

VERTOVEC, S. (2009) Transnationalism, Oxford, Routledge.

WILK, R. (1996) "Learning to be Local in Belize: Global Systems of Common Difference", in DANIEL MILLER (ed.) Worlds Apart. Modernity through the prism of the local. London, Routledge.

\section{Coisas e lugares da cidade. Práticas de consumo, assentamento e pertença de imigrantes de "segunda geração" em Lisboa}

\section{Resumo}

Apesar das migrações contemporâneas serem alvo de intensas e numerosas reflexões acadêmicas, existe relativamente pouca literatura sobre as suas interseções com a cultura material e as práticas de consumo. No entanto, os impactos das migrações sobre a materialidade fazem-se sentir muito para além dos objetos relacionados com a origem. Eles podem mudar as percepções dos sujeitos sobre si mesmos, reestruturar os seus padrões de interação social e alterar o equilíbrio de relações com aqueles que permaneceram na origem, bem como com aqueles que migraram para outras localidades e aqueles que partilham e vivem nos mesmos lugares.

Baseando-se nos resultados de uma pesquisa etnográfica realizada em Lisboa, com adolescentes com ascendência africana, este artigo tem como objetivo explorar a relação entre migração, materialidade e lugar e, mais especificamente, com o modo como trajetórias pessoais, culturais e geográficas, posicionamentos e pertenças políticas são marcadas e parcialmente constituídas através da relação com coisas produzidas em massa, adquiridas e utilizadas em contextos urbanos muito específicas. O artigo procura chamar a atenção para duas dimensões específicas. A primeira decorre do fato de que as coisas do quotidiano, tais como roupas, celulares, tênis, 
comida e música parecem ser apropriadas pelos jovens descendentes de emigrantes de acordo com lógicas específicas, com o objetivo de materializar identidades coletivas e estratégias de posicionamento em lugares-chave específicos, tais como o bairro, a escola ou o centro da cidade onde, por vezes, se deslocam. A segunda refere-se à existência de um processo de intensa circulação transnacional de objetos em curso, que informa a existência de uma rede social complexa baseada em várias localizações. Além de contribuir para a manutenção e/ou fortalecimento das relações familiares, a circulação contínua de coisas promove a produção de uma representação hierárquica do mundo - uma constelação de lugares diferentes, ligados por redes transnacionais complexas - e dos melhores destinos migratórios, com base nos objetos que são enviados e recebidos nos diferentes locais que a compõem.

Palavras-chave: mobilidade, lugar, juventude, cultura material, rede

\section{Las cosas y los lugares de la ciudad. Prácticas de consumo, el asentamiento y la pertenencia de los inmigrantes de "segunda generación" en Lisboa}

\section{Resumen}

A pesar que las migraciones contemporáneas han sido objeto de muchas reflexiones académicas, hay relativamente poca literatura sobre sus intersecciones con la cultura material y las prácticas de consumo. Sin embargo, el impacto de la migración sobre la materialidad se hace sentir más allá de los objetos relacionados con el origen. Las cosas pueden cambiar las percepciones de los sujetos sobre sí mismos, reestructurar sus patrones de interacción social y cambiar el equilibrio de las relaciones con los que se quedaron en casa, así como aquellos que han emigrado a otras partes y los que comparten y viven en los mismos lugares.

Con base en los resultados de un estudio etnográfico en Lisboa, con adolescentes de ascendencia africana, este artículo tiene como objetivo explorar la relación entre la migración, la materialidad y el lugar, más específicamente, con la forma como historias personales, culturales y de posicionamiento geográfico y afiliaciones políticas están marcadas y son parcialmente constituidas por la relación con las cosas producidas en masa, adquiridas y utilizadas en contextos urbanos muy específicos. El artículo pretende llamar la atención sobre dos dimensiones determinadas. La primera proviene del hecho de que las cosas cotidianas, tales como ropa, teléfonos celulares, tenis, comida y música parecen ser tomados por los jóvenes descendientes de emigrantes según lógicas específicas, con el objetivo de materializar identidades colectivas y estrategias de posicionamiento en lugares-clave específicos, como el barrio, la escuela o el centro de la ciudad donde a veces suelen moverse. El segundo se refiere a la existencia de una intensa circulación de objetos en curso, que informa la presencia de una red social compleja basada en varios lugares. Además de contribuir al mantenimiento y/o al fortalecimiento de las relaciones familiares, la circulación continua de cosas promueve la producción de una representación jerárquica del mundo - una constelación de diferentes lugares, conectados por redes transnacionales complejas - y los mejores destinos migratorios, sobre la base de objetos que se envían y se reciben en los diferentes locales que las componen.

Palabras-clave: movilidad, lugar, juventud, cultura material, red.

Data de recebimento do artigo: 30/01/2013

Data de aprovação do artigo: 16/05/2013 